\title{
The Relationship between Leadership Effectiveness of School Principals and Teachers Performance of Junior High Schools
}

\author{
Natasya Paquita Wibisono; Bambang Budi Wiyono; Wildan Zulkarnain \\ Jurusan Administrasi Pendidikan, Fakultas Ilmu Pendidikan, Universitas Negeri Malang, \\ Jl. Semarang No.5 Malang 65145 Kota Malang, Jawa Timur, Indonesia \\ E-mail: natasyapatrice@gmail.com
}

Article received: June 2021; revised: July 2021 ; accepted: August 2021

DOI : 10.17977/um025v5i32021p162

\begin{abstract}
The leadership effectiveness of school principals and teacher performance are two variables that determine school progress. With leadership effectiveness of the school principal and good teacher's performance will improve school performance. The question is whether the two variables are related. Therefore, this research aimed at determining the level of leadership effectiveness of the school principal, describing the level of teacher's performance, and determining the coefficient of the relationship between the leadership effectiveness of the school principal and teacher performance. This research was conducted in State Junior High Schools in Lowokwaru District, Malang City, using a simple correlation model quantitative research approach. The research sample was taken from 156 teachers with a proportional random sampling technique. Data collection techniques in this research employ a questionnaire and are processed with statistical data analysis techniques, descriptions, and Pearson Product moment correlation. The results of this research show that the level of the leadership effectiveness of the school principals is in the high category, while the teacher's performance level is in the medium category. There is a significant positive relationship between the leadership effectiveness of the school principals and teacher's performance. Based on these findings, to improve teachers' performance, it needs to improve the leadership effectiveness of the school principals.
\end{abstract}

Keywords: leadership effectiveness; performance; school principal; teacher

performance is a result or thing that is obtained from the work that has been achieved by a person in carrying out a task given to that person based on the presence of skills, as well as experience and sincerity in calculating time. Meanwhile, according to Siagian (2003), performance is a conceptual arrangement that is comprehensive and it can be said that operational effectiveness is also in an organization, part of the organization, and also part of a work based on predetermined standards or criteria. The evaluation of a teacher's performance also means a process to understand the level of performance that the teacher performs from one level to the next level. Assessment of work performance means that there is a process through the organization to evaluate or to assess the work performance of employees.

If it is examined more deeply, the quality of education depends a lot on teacher performance. Teacher performance is an essential job that can be achieved by a teacher at school with duties and responsibilities in achieving educational goals (Asf \& Mustofa, 2013). The success of a teacher is measured by the success of meeting the predetermined assignment criteria. If the teacher has met these criteria, it means that the teacher can be said as a successful teacher and has a good quality. Conversely, if a teacher has not met these criteria, then it can be said as a failed teacher. Teacher performance is influenced by several factors. These factors can come from within the individual teacher, such as motivation, skills, and education, and can also come from outside, including the leadership of the school principal. School 
principal leadership is closely related to teacher performance. Teacher performance can be maximized if the school principal has good leadership qualifications.

To find out the performance, it needs to do a performance appraisal. Performance appraisal is a very useful factor for developing an organization effectively and efficiently. A policy or program is better if it is supported by qualified human resources (HR) in the organization. Measurement of teacher performance indicators can be measured using instrument items that refer to the Minister of National Education Regulation Number 16 of 2007 which explains the qualifications of academic content and also teacher competence, namely knowing pedagogical competence, personal competence, social competence, and competence as a professional. The teacher performance in carrying out tasks is also shown by how high the four competencies can be applied in the implementation of daily tasks. This cannot be separated from the behavior of the school principal in implementing the leadership.

Every leader, including a school principal, in the process of carrying out the leadership function, will have their way and reflect the behavior (Zulkarnain, 2012). Effective school principals are leaders who can take an active role in raising awareness of the needs for school improvement as well as much higher expectations of achievement to get a consensus for change. On the other hand, the leadership effectiveness of the school principal is also defined as the success of executing activities to influence surroundings and achieve institutional goals. Leadership is very mean in the organization because leadership can be said to be successful if the management of the organization has a good leadership style, where one's techniques in leading can be known. Leadership has another meaning, it is the knowledge that is applied from the existing knowledge in a social discussion because the principles and formulations can provide hope to bring benefits to the welfare of all humans. Leadership is a process of influencing someone to manage their group members to achieve the targets of an organization and it can be successful if they can understand and do not forget to see the state of their surroundings, especially the institutional environment.

School is an educational organization. As an organization, its leadership, namely the school principal has to play a role like a leader who is full of responsibility for leading a school. The school principal should know the way to influence and provide motivation for the teacher to improve their performance. However, the conditions in the field are difficult, how effective is the leadership of the school principal, how the teacher performance, and how the relationship between these two variables is a question. Some research results show that leadership has a significant effect on teacher performance, but the results of other studies have not shown a strong effect. Servant leadership has a strong influence on teacher performance (Bakry and Syamril, 2021). The findings of Kusumaningrum et al also show that learning leadership, change leadership, spiritual leadership, school culture, and professional ethics affect teacher teaching performance (Kusumaningrum et al., 2020). The research results of Mustiningsih et al. (2020) indicated that the components of the principal's visionary leadership, which consist of policy reconstructors, direction determinants, change agents, spokespersons, trainers, have a direct contribution to teacher readiness in facing the industrial revolution 4.0, either simultaneously or partially. The leadership style applied by the principal does not only affect performance, but also competence. Changes in leadership style will affect the increase or decrease in teacher competence (Zuhri and Sugiyarti, 2018).

Based on the previous studies, it is suspected that the leadership effectiveness of the school principal has a big influence in determining teacher performance, but it still requires empirical study. For this reason, this research was conducted. The hypothesis of the research is there is a relationship between the leadership effectiveness of school principals and teacher's performance in junior high schools.

\section{METHODS}

The quantitative research approach is a simple correlation model. Quantitative research uses numerical logic in the research process, by emphasizing the analysis of data presented in the form of numbers. The research design used in this research is descriptive correlational. There are two variables studied, the leadership effectiveness of the school principal (X), and the performance of the teachers (Y). The research design can be presented in the form of Figure 1. 


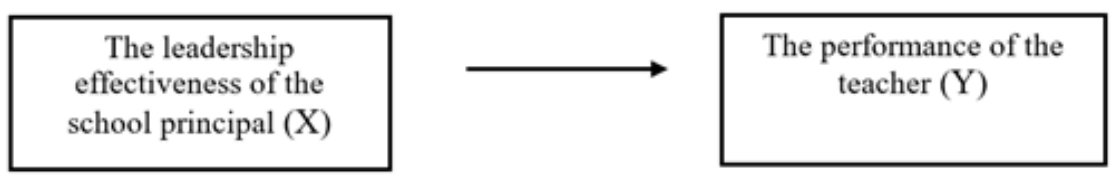

Figure 1. Relationship between Variables

Information :

$\mathrm{X} \quad=$ leadership of the school principals

$\mathrm{Y} \quad=$ teachers performance

$=$ relationship between variables

The research was conducted in State Junior High Schools in Lowokwaru District, Malang City, with a total population of 256 teachers. The research sample was taken of 156 with a proportional random sampling technique. The data collection technique was using a questionnaire. The research instrument was developed based on the construct of research variables in the form of a questionnaire. Before it was being used, the instrument was tested. Based on the test results, it is known that the instrument items are declared valid with the coefficient of each item, $r>0.3$, and reliable with the results of the Cronbach formula reliability analysis, $r_{i i}>0.7$.

In accordance with the research objectives, the data analysis technique utilizes descriptive statistics and Pearson product-moment correlation analysis techniques. The data normality test uses the Kolmogorov-Smirnov. In conducting data analysis, it employs the assistance of the IBM Statistical Package for Social Science (SPSS) application version 24.0.

\section{RESULTS AND DISCUSSION}

\section{Leadership effectiveness of the school principals}

The first variable to be analyzed was the leadership effectiveness of the school principals. The results of data analysis, in general, are presented in Table 1

Table 1. Value Interval of The Leadership Effectiveness of School Principals (X)

\begin{tabular}{llccccc}
\hline No & Alternative Answers & Code & Interval & Category & Frequency & Percentage (\%) \\
\hline 1 & SS & 4 & $90-96$ & Very high & 23 & 14.7 \\
2 & S & 3 & $84-89$ & High & 64 & 41 \\
3 & TS & 2 & $78-83$ & Moderate & 55 & 35.3 \\
4 & STS & 1 & $72-77$ & Low & 14 & 9 \\
& & Total & & & 156 & 100.0 \\
\hline
\end{tabular}

Based on Table 1, the results of descriptive analysis using IBM SPSS Statistic 24 indicate that the maximum score $=96$; minimum score $=72$; and mean $=84.29$. After knowing the maximum score and minimum score, then the range of interval class scores is looked for to determine the leadership effectiveness of the school principals. Based on the analysis of 156 teachers, the results obtained 23 teachers $(14.7 \%)$ who answered that the leadership effectiveness of the school principals was in very high qualifications, 64 teachers $(41 \%)$ stated that the leadership effectiveness of the school principals was in high qualification. 55 teachers (35.3\%) stated that the leadership effectiveness of the school principals was in moderate qualifications, and 14 teachers $(9 \%)$ stated that the leadership effectiveness of the school principals was in a low qualification. Then the mean value for the principal leadership effectiveness variable, namely 84.29 , is in the 84-89 interval, this is in the high category, with the average frequency percentage of its value of $84.29 \%$. The description of the results of the data analysis can be presented in the form of Figure 2. 


\section{Keefektifan Kepemimpinan Kepala Sekolah}

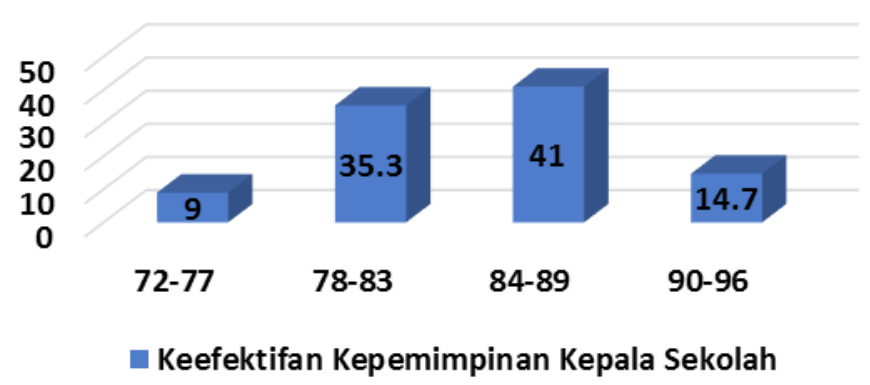

Figure 2. Variable Interval Frequency Bar Chart X

\section{Teacher performance}

Based on the results of data analysis, teacher's performance is generally presented in Table 2.

Table 2. Value Interval of Teacher Performance (Y)

\begin{tabular}{llccccc}
\hline No & Alternative Answers & Code & Interval & Category & Frequency & Percentage (\%) \\
\hline 1 & SS & 4 & $189-199$ & Very high & 12 & 7.7 \\
2 & S & 3 & $178-188$ & High & 35 & 22.4 \\
3 & TS & 2 & $167-177$ & Moderate & 73 & 46.8 \\
4 & STS & 1 & $156-166$ & Low & 36 & 23.1 \\
& & & & 156 & 100.0 \\
\hline
\end{tabular}

Based on Table 2, the results of descriptive analysis using IBM SPSS Statistic 24 show that the maximum score $=199$; minimum score $=156$; and the average or mean value $=173.66$. Based on the results of this research, it shows that from the total of 156 respondents, 12 teachers $(7.7 \%)$ of respondents indicated that teacher performance was in very high qualifications, 35 teachers $(22.4 \%)$ of respondents indicated that teacher performance was in high qualifications. , 73 teachers $(46.8 \%)$ of respondents stated that the performance of teachers was in moderate qualifications, and 36 teachers $(23.1 \%)$ of respondents indicated that the performance of the teachers was in low qualifications.

Based on these results, the conclusion is that the teacher's performance level of Junior High schools in Lowokwaru District, Malang City is in the medium category, with a percentage of $173.66 \%$. From these results, teacher's performance needs to be continuously improved to achieve better and maximum performance. These results can be presented in the form of Figure 3.

\section{Kinerja Guru}

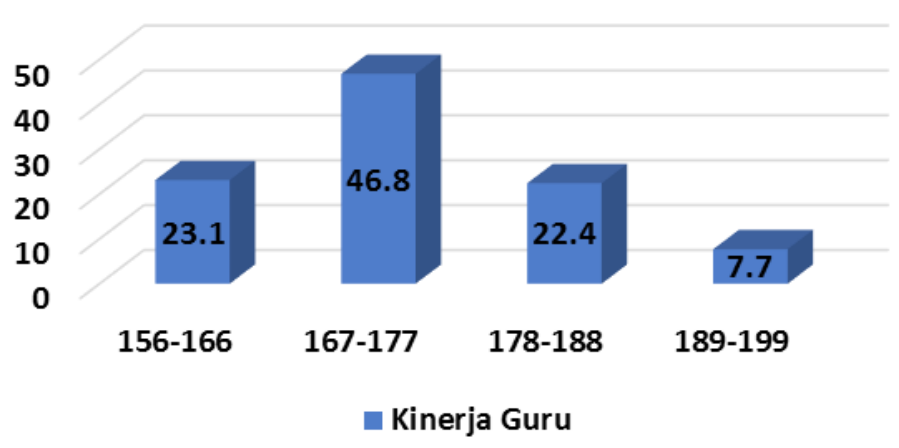

Figure3. Variable Interval Frequency Bar Chart Y 
Furthermore, the research hypothesis testing is carried out. In accordance with the type of data and research objectives, hypothesis testing is carried out using the Pearson Product Moment correlation analysis technique.

\section{Hypothesis Test}

Based on the results of data analysis, a correlation coefficient of 0.645 was obtained with a significance level (probability error) $<0.05$. This explains that there is a significant positive relationship between the leadership effectiveness of the school principals and the performance of the teachers of State Junior High Schools in Lowokwaru District, Malang City. The results of statistical tests show that $\mathrm{H} 0$ is rejected, and $\mathrm{H} 1$ is accepted. Thus, it can be concluded that there is a significant positive relationship between the leadership effectiveness of school principals and teacher's performance. The higher the leadership effectiveness of the school principals, the higher the teachers' performance in carrying out their duties.

Based on the results obtained before, it can be concluded that there is a positive and significant relationship between the leadership effectiveness of the school principal and the performance of the teachers of State Junior High Schools in Lowokwaru District, Malang City. As for the level of the relationship between variables when viewed through the results of the correlation test, it can be concluded that the level of correlation, or the relationship between the leadership effectiveness of the school principal and the performance of teachers in Lowokwaru District, Malang City is in a strong category.

The Pearson Product Moment value on the leadership effectiveness of school principal variable (X) which includes two sub-variables, for the first sub variable, namely leadership characteristics, contributed 0.557 , and for the second sub variable, leadership behavior of 0.514 , and based on the total variable X (leadership effectiveness of the school principal), so that a significant value can be obtained with a p-value of $0.000<0.05$ which means significant and has a positive correlation. Whereas, for the Pearson Product Moment value on the teacher's performance variable (Y) which consists of two subvariables, for the first sub variable, namely the performance factor contributes 0.653 , and for the second sub variable, and the performance criteria is 0.490 , and based on the total variable Y (performance teacher) obtained a value for significance also of $0.000<0.05$, which means that it is significant and has a positive correlation.

The next discussion is that a leader can affect teacher performance, this can be achieved for organizational goals, leaders are closely related to teacher performance, and besides that, training is also needed to improve the quality of teacher performance. If a leader can work effectively in his performance, then it will also encourage and improve teacher performance in carrying out duties. This is also following the results of research conducted by Mufidah (2009) which explains that there is a direct and significant relationship between the leadership of the school principal and the performance of school administrative personnel at SMPTN Malang City.

Based on the results of the calculation of the level of the relationship between the leadership effectiveness of the principals and the performance of the teachers of State Junior High Schools in Lowokwaru, Malang City, which are in the strong category, it shows that the school has succeeded in improving teachers performance through the leadership effectiveness of the school principals, and vice versa. If a leader can work effectively in his performance, it will directly encourage and improve teacher performance in carrying out duties. The role of a school principal in realizing teacher performance is very large, in this case also considering that there is effective leadership, teacher performance will follow. So it can be concluded that the leadership effectiveness of the principals and teacher performance are directly related to each other.

The results of this study are also in line with Wiyono's (2018) research which shows that the school principal's transformational leadership affects teacher work motivation and work effectiveness. The results of this study are also following the results of research by Bafadal et al (2019) which show that the quality of school-based management affects teacher work motivation and school quality. The higher the quality of school principal management, the higher the teacher's work motivation in carrying out tasks, 
and the higher the quality of education in schools. The findings of Ariyanti et al., (2021) also indicated that situational leadership, emotional quotient, and achievement motivation have a direct influence on employee performance partially and simultaneously. The other research results also indicated that the transformational leadership of the school principals had a significantly positive influence in motivating the teachers' work motivation (Wiyono, 2017).

The effectiveness of leadership is largely determined by the quality of management. Management quality is a competency related to the leadership of the school principal. In fact, the 2007 Minister of National Education Regulation included leadership skills in managerial competencies. The quality of management has an impact on the quality of education in schools (Wiyono, 2017). Leadership and management are variables that determine improving the quality of education in schools (Wibawani et al., 2019). In addition, the principal's leadership is decisive in increasing competitiveness. With excellent leadership will be able to improve qualified human resources, and with the increase in qualified human resources will produce excellent students (Nindiatika et al., 2019). Thus, it can be concluded that the results of this study reinforce the results of previous studies. The higher the leadership effectiveness of the school principal, the higher the teacher's performance in carrying out tasks.

\section{CONCLUSION}

Based on the results of the research that has been conducted, several main conclusions can be formulated. First, the level of leadership effectiveness of the school principal of State Junior High Schools in Lowokwaru District, Malang City is in the high category. Second, the teacher's performance level of State Junior High schools in Lowokwaru District, Malang City is in the medium category. Third, there is a significant positive relationship between the leadership effectiveness of the school principal and the performance of the teachers of State Junior High schools in Lowokwaru District, Malang City. The relationship coefficient is included in the strong category. Increasing the leadership effectiveness of the school principals factor and teacher's performance can simultaneously encourage stronger results, and are in the high category. The higher the leadership effectiveness of the school principal, the higher the teacher's performance in carrying out tasks.

Based on the research findings, it is suggested to school principals or officials in the education office to improve the leadership effectiveness of the school principal, to improve teacher performance. The results of the research indicate that the teacher performance is still in the moderate category. Therefore, it still needs to improve to a high or very high category. Thus, it will increase the success and progress of the school. For further researchers, there are still many other variables that have not been studied in this research, including when it is referring to the competency dimensions of the school principal, one of the competencies that are closely related is the competence of supervision. To improve teacher's performance, especially for the improvement of teaching quality, the most appropriate supervision strategy for school principals to implement. Therefore, this problem would be better studied by further researchers, to obtain more comprehensive results.

\section{REFERENCES}

Ariyanti, N.S., Adha, M.A., Wiyono, B.B., Timan, A., Burhanuddin, Mustiningsih, 2021. The effect of situational leadership of the head of administration, emotional quotient, and achievement motivation on employee performance at State University of Malang. AIP Conference Proceedings 2339, 020165. https://doi. org/10.1063/5.0044894

Asf, J., dan Mustofa, S. 2013. Terobosan Baru didalam Kinerja Peningkatan Kerja Pengawas Sekolah \& Guru. Yogyakarta: Ar-Ruzz Media.

Bafadal, I., Wiyono, B.B. dan Sobri, A.Y. 2019. The Implementation of School-Based Management, and Its Effect on the Teachers' Work Motivation and the School Quality. Universal Journal of Educational Research, 7(9): 2021-http://www.hrpub.org DOI: 10.13189/ujer.2019.070925

Bakry, B., Syamril, S., 2021. Pengaruh Servant Leadership terhadap Nilai Kinerja Guru. JMSP (Jurnal Manajemen dan Supervisi Pendidikan) 5, 24-28. https://doi.org/10.17977/um025v5i12020p298 
Kusumaningrum, D.E., Sumarsono, R.B., Gunawan, I., 2020. Pengaruh Kepemimpinan Pembelajaran, Kepemimpinan Perubahan, Kepemimpinan Spiritual, Budaya Sekolah, dan Etika Profesi terhadap Kinerja Mengajar Guru. JMSP (Jurnal Manajemen dan Supervisi Pendidikan) 4, 198-219. https://doi.org/10.17977/ um025v4i32020p198

Mufidah, I. 2009. Hubungan Gaya Kepemimpinan Kepala Sekolah dan Iklim Sekolah dengan Kinerja Tenaga Administrasi Sekolah (TAS) di SMPTN Kota Malang. Jurnal Pendidikan. http://mulok.library.um.ac.id/ home.php?sdata=Skripsi\&id=39461\&mod=b\&cat=4. Diakses pada 10 Maret 2019.

Mustiningsih, M., Maisyaroh, M., Ulfatin, N., 2020. Peran Kepemimpinan Visioner Kepala Sekolah Hubungannya dengan Kesiaapan Guru Menyongsong Revolusi Industri 4.0. JMSP (Jurnal Manajemen dan Supervisi Pendidikan) 4, 101-112. https://doi.org/10.17977/um025v4i22020p101

Nindiantika, V., Ulfatin, N., Juharyanto, J., 2019. Kepemimpinan Situasional untuk Meningkatkan Daya Saing Luaran Pendidikan Abad 21. JAMP : Jurnal Administrasi dan Manajemen Pendidikan 2, 40-48. https://doi. org/10.17977/um027v2i22019p40

Peraturan Menteri Pendidikan Nasional Nomor 16 Tahun 2007 Tentang Kualifikasi Akademik dan Kompetensi Guru. (Online). http://vervalsp.data.kemdikbud.go.id/prosespembelajaran/file/Permendiknas\%20No\%20 16\%20Tahun\%202007.pdf. Diakses pada 20 Juni 2020.

Siagian, S.P. 2003. Teori dan Praktek Kepemimpinan. Jakarta: Rineka Cipta.

Zulkarnain, W. 2012. Gaya Kepemimpinan Managerial Grid Kepala Sekolah Dasar. Jurnal Manajemen Pendidikan, 23(6), 497-503. http://ap.fip.um.ac.id/wp-content/uploads/2015/05/volume-23-no.-614-21.pdf

Wibawani, D.T., Wiyono, B.B., Benty, D.D.N., 2019. Kepemimpinan Visioner Kepala Sekolah sebagai Pemimpin Perubahan dalam Peningkatan Mutu Pendidikan. JAMP : Jurnal Administrasi dan Manajemen Pendidikan 2, 181-187. https://doi.org/10.17977/um027v2i42019p181

Wiyono, B.B., 2017. The Effect of School-Based Management Implementation on the Education Quality. Advanced Science Letters 23, 8612-8616. https://doi.org/10.1166/asl.2017.9939

Wiyono, B.B., Wiyono, B.B., 2017. The Effectiveness of the Implementation of Principals'

Transformational Leadership in Motivating Teachers to Carry Out Their Profession Duties. IJLT. https://doi. org/10.18178/ijlt.3.2.144-147

Zuhry, A.W., Sugiyarti, G., 2018. Pengaruh Gaya Kepemimpinan, Diklat Struktural, Komitmen Organisasi terhadap Kompetensi. JMSP (Jurnal Manajemen dan Supervisi Pendidikan) 3, 1-11. https://doi.org/10.17977/ um025v3i12018p001

Wiyono, B.B. 2018. The effect of self-evaluation on the principals' transformational leadership, teachers' work motivation, teamwork effectiveness, and school improvement. International Journal of Leadership in Education, 21(6): 705-725.

https://www.tandfonline.com/doi/full/10.1080/13603124.2017.1318960

Wiyono, B.B. 2017. The Effectiveness of the Implementation of Principals' Transformational Leadership in Motivating Teachers to Carry Out Their Profession Duties. IJLT. https://doi.org/10.18178/ijlt.3.2.144-147

Wiyono, B.B., 2017. The Effect of School-Based Management Implementation on the Education Quality. Advanced Science Letters 23, 8612-8616. https://doi.org/10.1166/asl.2017.9939

Zuhry, A.W., Sugiyarti, G., 2018. Pengaruh Gaya Kepemimpinan, Diklat Struktural, Komitmen Organisasi terhadap Kompetensi. JMSP (Jurnal Manajemen dan Supervisi Pendidikan) 3, 1-11. https://doi.org/10.17977/ um025v3i12018p001 